\title{
Genotoxicity of Aluminum and Aluminum Oxide Nanomaterials in Rats Following Oral Exposure
}

\author{
Pégah Jalili ${ }^{1}$, Sylvie Huet ${ }^{1}$, Rachelle Lanceleur ${ }^{1}$, Gérard Jarry ${ }^{1}$, Ludovic Le Hegarat ${ }^{1}{ }^{1}$, \\ Fabrice Nesslany ${ }^{2}$, Kevin Hogeveen ${ }^{1}$ and Valérie Fessard ${ }^{1, *}$ \\ 1 Unité de Toxicologie des Contaminants, Agence Nationale de Sécurité Sanitaire (ANSES), 10 B rue Claude \\ Bourgelat, 35306 Fougères, France; pjalili@uci.edu (P.J.); sylvie.huet@anses.fr (S.H.); \\ rachelle.lanceleur@anses.fr (R.L.); gerard.jarry@anses.fr (G.J.); ludovic.lehegarat@anses.fr (L.L.H.); \\ kevin.hogeveen@anses.fr (K.H.) \\ 2 Institut Pasteur de Lille, Laboratoire de toxicologie génétique, 1 Rue du Professeur Calmette, 59019 Lille \\ CEDEX, France; fabrice.nesslany@pasteur-lille.fr \\ * Correspondence: Valerie.fessard@anses.fr; Tel.: +33-(0)2-9994-6685
}

Received: 9 January 2020; Accepted: 2 February 2020; Published: 11 February 2020

check for updates

\begin{abstract}
Due to several gaps remaining in the toxicological evaluation of nanomaterials (NMs), consumers and public health agencies have shown increasing concern for human health protection. In addition to aluminum (Al) microparticles, $\mathrm{Al}$-containing nanomaterials ( $\mathrm{Al} \mathrm{NMs)} \mathrm{have} \mathrm{been}$ applied by food industry as additives and contact materials. Due to the limited amount of literature on the toxicity of $\mathrm{Al} \mathrm{NMs,} \mathrm{this} \mathrm{study} \mathrm{aimed} \mathrm{to} \mathrm{evaluate} \mathrm{the} \mathrm{in} \mathrm{vivo} \mathrm{genotoxic} \mathrm{potential} \mathrm{of} \mathrm{Al}^{0}$ and $\mathrm{Al}_{2} \mathrm{O}_{3} \mathrm{NMs}$ after acute oral exposure. Male Sprague-Dawley rats were administered three successive gavages at $6,12.5$ and $25 \mathrm{mg} / \mathrm{kg}$ bw. A comparison with $\mathrm{AlCl}_{3}$ was done in order to assess the potential effect of dissolution into $\mathrm{Al}$ ions. Both DNA strand breaks and oxidative DNA damage were investigated in six organs/tissues (duodenum, liver, kidney, spleen, blood and bone marrow) with the alkaline and the Fpg-modified comet assays. Concomitantly, chromosomal damage was investigated in bone marrow and colon with the micronucleus assay. The comet assay only showed DNA damage with $\mathrm{Al}_{2} \mathrm{O}_{3} \mathrm{NMs}$ in bone marrow $(\mathrm{BM})$, while $\mathrm{AlCl}_{3}$ induced slight but non-significant oxidative DNA damage in blood. No increase of chromosomal mutations was observed after treatment with the two $\mathrm{Al} \mathrm{MNs}$ either in the $\mathrm{BM}$ or in the colons of rats.
\end{abstract}

Keywords: genotoxicity; comet assay; micronucleus assay; nanomaterial; aluminum; oral route; gut; liver

\section{Introduction}

Micro-and nanoscale forms of aluminum (Al) have a great lightness and mechanical resistance, and strong oxidizing power [1]. Due to these unique properties, $\mathrm{Al}$ microparticles and Al-containing nanomaterials (Al NMs) have been applied by industry, including in food products [2]. Indeed, they are used as food additives (firming agents, anticaking agents, neutralizing agents, emulsifying agents or texturizers) and in food contact materials, such as cooking tools and food packaging [1-5]. In addition, Al-containing particles are largely used in waste water treatment [6], and in drug vehicles, dental products and other hygiene products, such as toothpaste [1,7-9].

According to the European Food Safety Authority (EFSA) and the Food and Agriculture Organization/World Health of the United Nations (FAO/WHO), provisional tolerable weekly intakes of 1 and $2.3 \mathrm{mg} \mathrm{Al} / \mathrm{kg} /$ week have been established respectively [1,10]. However, these organizations have raised the fact that this amount can be exceeded to a large extent by some populations, particularly children. As recurrent exposure to micro- and nanoscale $\mathrm{Al}$ particles for the general population occurs 
through foodstuffs, hazard assessment through ingestion should be addressed. Nevertheless, several gaps remain in the toxicological evaluation of Al NMs following oral exposure, which may raise the concern already outlined concerning $\mathrm{Al}$ by consumers and public health agencies.

Few in vivo studies are available on the oral toxicity and genotoxicity of Al NMs, most of them focusing on $\mathrm{Al}_{2} \mathrm{O}_{3} \mathrm{NMs}$. These NMs were shown to accumulate in several organs, including the liver following oral exposure [11-13]. Rodents treated orally with 500 to $2000 \mathrm{mg} / \mathrm{kg}$ bw of $\mathrm{Al}_{2} \mathrm{O}_{3}$ NMs showed deleterious effects in the liver and kidney, and genotoxicity in bone marrow (BM) and oxidative stress in liver [11,14]. According to the ECHA's safety assessment, the data available are inconclusive as to whether or not $\mathrm{Al}_{2} \mathrm{O}_{3} \mathrm{NMs}$ present a genotoxic potential [15]. In contrast, no data on the genotoxicity of $\mathrm{Al}^{0} \mathrm{NMs}$ have been published so far, either in vitro or in vivo.

In vitro studies reported that $\mathrm{Al}_{2} \mathrm{O}_{3} \mathrm{NMs}$ can induce genotoxicity in a variety of mammalian cell lines, including primary human fibroblasts [16], hepatic HepG2 cells [17], human peripheral lymphocytes [18] and Chinese hamster ovary cells (CHO-K1) [19]. These genotoxic effects were found to be associated with oxidative damage [17] although other studies reported no association $[16,19]$.

In addition, there is a lack of information concerning the mechanisms involved, and whether the release of the ionic compound can be the cause of genotoxicity. Indeed, the metal salt $\mathrm{AlCl}_{3}$ has been shown to induce DNA damage in vitro in human peripheral blood lymphocytes, including increases in micronuclei and chromosomal aberrations and positive results in the comet assay [20-22]. In vivo, Paz et al. (2017) reported histopathological lesions in the stomach and the liver, and increased chromosomal damage in BM from $50 \mathrm{mg} / \mathrm{kg}$ bw after unique oral exposures to mice [22].

In this study, we aimed to provide new genotoxicity data for $\mathrm{Al}^{0}$ and $\mathrm{Al}_{2} \mathrm{O}_{3} \mathrm{NMs}$ and to do a comparison with $\mathrm{AlCl}_{3}$. For this purpose, we conducted an in vivo study in rats by gavage. After three oral administrations, the alkaline and Fpg-modified comet assays were performed on several organs to detect DNA breaks and the micronucleus assay to detect if any chromosomal damage could be induced in bone marrow and the colon.

\section{Material and Methods}

\subsection{Chemicals, NMs and Dispersion}

$\mathrm{AlCl}_{3}$ (hexahydrate, 231-208-1) was purchased from Sigma Aldrich (Saint Louis, MO, USA).

The selected $\mathrm{Al}^{0}$ and $\mathrm{Al}_{2} \mathrm{O}_{3} \mathrm{NMs}$ were obtained from IoLiTec (Heilbronn, Germany) and were chosen with a similar primary particle size (approximately $20 \mathrm{~nm}$ ). The NANOGENOTOX protocol was used for NM dispersion [23,24]. Briefly, particle powder was dispersed in a scintillation vial at a concentration of $2.56 \mathrm{mg} / \mathrm{mL}$ in $0.05 \%$ BSA in ultra-pure water (dispersion stock solution) by sonication in ice for $16 \mathrm{~min}$ at $400 \mathrm{~W}$ using a Branson ultrasonic sonicator (Branson Ultrasonics, Eemnes, Netherlands) with a $13 \mathrm{~mm}$ probe diameter. Several parameters of physicochemical characterization in the dispersion stock solution and those provided by the suppliers are summarized in Table 1. A more detailed description of the physicochemical characterization of the two NMs was published previously $[25,26]$. 
Table 1. Summary of nanomaterial (NM) characteristics.

\begin{tabular}{|c|c|c|c|c|c|c|c|c|c|}
\hline NM & NM-Code & $\begin{array}{c}\text { Average } \\
\text { Particle } \\
\text { Size } \\
\text { (nm) }\end{array}$ & $\begin{array}{l}\operatorname{SSA}^{b} \\
\left(\mathrm{~m}^{2} / \mathrm{g}\right)\end{array}$ & Purity ${ }^{c}$ & $\begin{array}{l}\text { Bulk Density, } \\
\text { True Density } \\
\left(\mathrm{g} / \mathrm{cm}^{3}\right)\end{array}$ & Morpholo & $\mathrm{yPdi}^{\mathrm{e}}$ & $\begin{array}{l}\text { Z-Average } \\
\text { Size in the } \\
\text { Stock Solution } \\
\text { Dispersion at } \\
0 \mathrm{~h}^{\mathrm{e}}(\mathrm{nm})\end{array}$ & $\begin{array}{c}\text { Solubility } \\
\text { f }(24 h) \\
(\%)\end{array}$ \\
\hline $\mathrm{Al}^{0}$ & NM-0015-HP & 18 & $40-60$ & $>99 \%$ & $\begin{array}{c}2.7 \\
0.008-0.2\end{array}$ & Spherical & $\begin{array}{c}0.17 \pm \\
0.004\end{array}$ & $254 \pm 4$ & $\begin{array}{c}0.48 \pm \\
0.02\end{array}$ \\
\hline$\gamma-\mathrm{Al}_{2} \mathbf{o}_{3}$ & NM-0036-HP & 20 & $<200$ & $99 \%$ & $\begin{array}{c}- \\
0.9\end{array}$ & Spherical & $\begin{array}{c}0.23 \pm \\
0.015\end{array}$ & $168 \pm 3$ & $\begin{array}{c}0.15 \pm \\
0.01\end{array}$ \\
\hline
\end{tabular}

a Average particle size was determined by TEM. ${ }^{b}$ Average specific surface area (SSA) was determined by Brunauer-Emmet-Teller (BET). Purity was determined by X-ray powder diffraction (XRD). ${ }^{\mathrm{d}}$ Density was assessed by normal volumetric test. ${ }^{e}$ Pdi and Z-average size were assessed by dynamic light scattering (DLS) using Malvern Zetasizer (Malvern Instruments, Malvern, UK) equipped with a 633-nm laser diode operating at an angle of $173^{\circ} . \mathrm{f}$ Ion release was performed using with a quadrupole inductively coupled plasma mass spectrometry (ICP-MS). ${ }^{a, b, c, d}$ Information provided from the supplier. ${ }^{\mathrm{e}, \mathrm{f}}$ Dispersion stock solution.

\subsection{Animals and Experimental Design}

Male Sprague-Dawley (SD) rats, 8-10 weeks old (around $200 \mathrm{~g}$ ), were purchased from Janvier (Saint Berthevin, France). Rats were housed in conventional cages and had free access to water and food. Temperature and humidity were kept constant with a light/dark cycle of $12 \mathrm{~h} / 12 \mathrm{~h}$. The animals were treated after at least 5 days of acclimatization. All the experiments were in accordance with the ethical recommendations of the Directive 2010/63/EU of the European Parliament and were validated by the Anses ethical committee (COMETH). Five animals per group were randomly assigned to nine groups including negative and positive controls.

Animals were treated by oral gavage $(9.76 \mathrm{~mL} / \mathrm{kg})$ at 0,24 and $45 \mathrm{~h}$. Animals were sacrificed $3 \mathrm{~h}$ after the last administration. $\mathrm{Al}^{0}$ and $\mathrm{Al}_{2} \mathrm{O}_{3} \mathrm{NMs}$ were given at $6,12.5$ and $25 \mathrm{mg} / \mathrm{kg}$ bw, and $\mathrm{AlCl}_{3}$ was given at $25 \mathrm{mg} / \mathrm{kg}$ bw. We chose to give a similar mass of compounds to the animals. Nevertheless, the content of Al per animal differed according to the material administered (Table S1). Ultra-pure water with $0.05 \%$ BSA was used as vehicle for the negative control group. The positive control was methyl methane sulfonate (MMS from Acros, Geel, Belgium) at $100 \mathrm{mg} / \mathrm{kg}$ for the first two oral administrations and at $80 \mathrm{mg} / \mathrm{kg}$ for the third. The experimental design was carried out according to the OECD guideline 489 for the comet assay [27].

\subsection{Tissue Collection and Sample Preparation}

Animals were anesthetized with an intraperitoneal sublethal dose of pentobarbital $(60 \mathrm{mg} / \mathrm{kg})$, and the following samples were collected: blood, bone marrow from femur, liver, spleen, kidney, duodenum and colon.

For the comet assay, cells or nuclei were isolated as described in Tarantini et al. (2015) [28]. Briefly, blood was collected directly from the heart before a perfusion step; nuclei of the liver and kidney were mechanically isolated from few small pieces using a Medimachine (BD Biosciences, Le-Pont-de-Claix, France) ( $5 \mathrm{~s}$ in the grinding medium). Spleen cells were harvested by flushing. Sections of duodenum and colon were rinsed with Hank's balanced salt solution (HBSS) medium and epithelial cells were collected by scraping with a coverslip. The rest of the colon and bone marrow cells collected from the two femurs by aspiration with fetal bovine serum were further prepared for the micronucleus assay as described below.

\subsection{Alkaline Comet Assay and FpG-Modified Comet Assay}

Briefly, after isolation from organs, cells were centrifuged $5 \mathrm{~min}$ at $136 \times g$, and the alkaline comet assay and the modified comet assay using the bacterial DNA repair enzyme formamidopyrimidine-DNA glycosylase (Fpg) were performed (2 slides per organ and condition, migration $24 \mathrm{~min}, 0.7 \mathrm{~V} / \mathrm{cm}$ and $300 \mathrm{~mA}$ ) as previously described [28]. FpG (5U/slide) favors the detection of oxidized bases by catalyzing excision of oxidized purines, including the major purine oxidation product 8-oxoguanine, 
into single-strand breaks [29]. For each tissue and condition (with and without FpG), two slides were prepared. Before scoring, slides were coded, stained with propidium iodide ( $2.5 \mu \mathrm{g} / \mathrm{mL}$ in PBS) and immediately observed with a fluorescence microscope (Leica DMR, Nanterre, France) equipped with a CCD-200E camera. For each slide, 75 nucleoids were scored using the Comet Assay IV software (Perceptive Instruments, Haverhill, UK). The percentage of DNA in the tail (\% Tail DNA) was chosen to evaluate DNA damage. The mean of the median tail intensity value of each slide was calculated for each animal, prior to the calculation of the mean value of each group. When DNA damage was too high to score, the cells were counted as hedgehogs [30,31].

\subsection{Bone Marrow Micronucleus Assay (BMMN)}

The BMMN assay was carried out following the general principles of the OECD guideline 474 [32]. Briefly, after isolation and centrifugation for $5 \mathrm{~min}$ at $210 \times \mathrm{g}$, drops of BM cells were spread on a microscope slide and allowed to air dry half a day. After fixation in ethanol $96^{\circ}$, the smears were stained for 3 min with May-Grünwald (MG) reagent, 2 min in MG diluted in Sörensen buffer (50/50V, pH $6.75 \pm 0.05), 10 \mathrm{~min}$ in $14 \%$ Giemsa and $1 \mathrm{~min}$ in demineralized water. Duplicate slides were prepared for each animal. At least 2000 polychromatic erythrocytes (PCEs) per slide were examined microscopically to determine the frequency of micronucleated polychromatic erythrocytes (MN-PCEs). For myelotoxicity evaluation, the ratio of PCEs to normochromatic erythrocytes (NCEs) was calculated. Coded slides were analyzed under a bright field microscope and micronuclei were scored by two independent scorers.

\subsection{Colon Micronucleus Assay}

The "swiss roll" technique was performed as previously described [28]. The whole colon was cut longitudinally prior to a wash with HBSS. The tissue was rolled up from the rectum to the caecum with the mucosa inward, fixed in $4 \%$ formaldehyde and embedded in paraffin. Sections were deparaffinized and dehydrated twice in toluene followed by successive baths of ethanol $100 \%, 95 \%$ and $70 \%$. After rinsing and staining with Schiff's reagent (Saint Louis, MO, USA) and fast green, a dehydration step in ethanol $70^{\circ}$ and ethanol $96^{\circ}$ was performed, and finally, slides were mounted using DPX. Intact colon crypts were chosen, and scoring was done on at least 1000 cells per rat.

\subsection{Statistical Analysis}

For the in vivo comet assay, the results from the five animals were analyzed using a one-way ANOVA. For the bone marrow and colon MN assays, Pearson's chi square test with Yate's correction was used. Myelotoxicity and hedgehogs over the vehicle control were analyzed with the MannWhitney U test (one tailed). Statistical significance was set at $p<0.05$.

\section{Results}

\subsection{Comet Assay}

The results from the alkaline comet assay after three oral treatments with $\mathrm{Al}^{0} \mathrm{NMs}$ and $\mathrm{Al}_{2} \mathrm{O}_{3}$ $\mathrm{NMs}$ at $6,12.5$ or $25 \mathrm{mg} / \mathrm{kg}$ bw/day, and $\mathrm{AlCl}_{3}$ at $25 \mathrm{mg} / \mathrm{kg}$ bw/day, are shown in Figure 1 . $\mathrm{Al}^{0} \mathrm{NMs}$ did not induce an increase in tail intensity irrespective of the organ or tissue investigated compared to the vehicle control group. $\mathrm{Al}_{2} \mathrm{O}_{3} \mathrm{NMs}$ induced a significant increase in tail intensity only in $\mathrm{BM}$ at the highest dose $(25 \mathrm{mg} / \mathrm{kg} \mathrm{bw})$. 


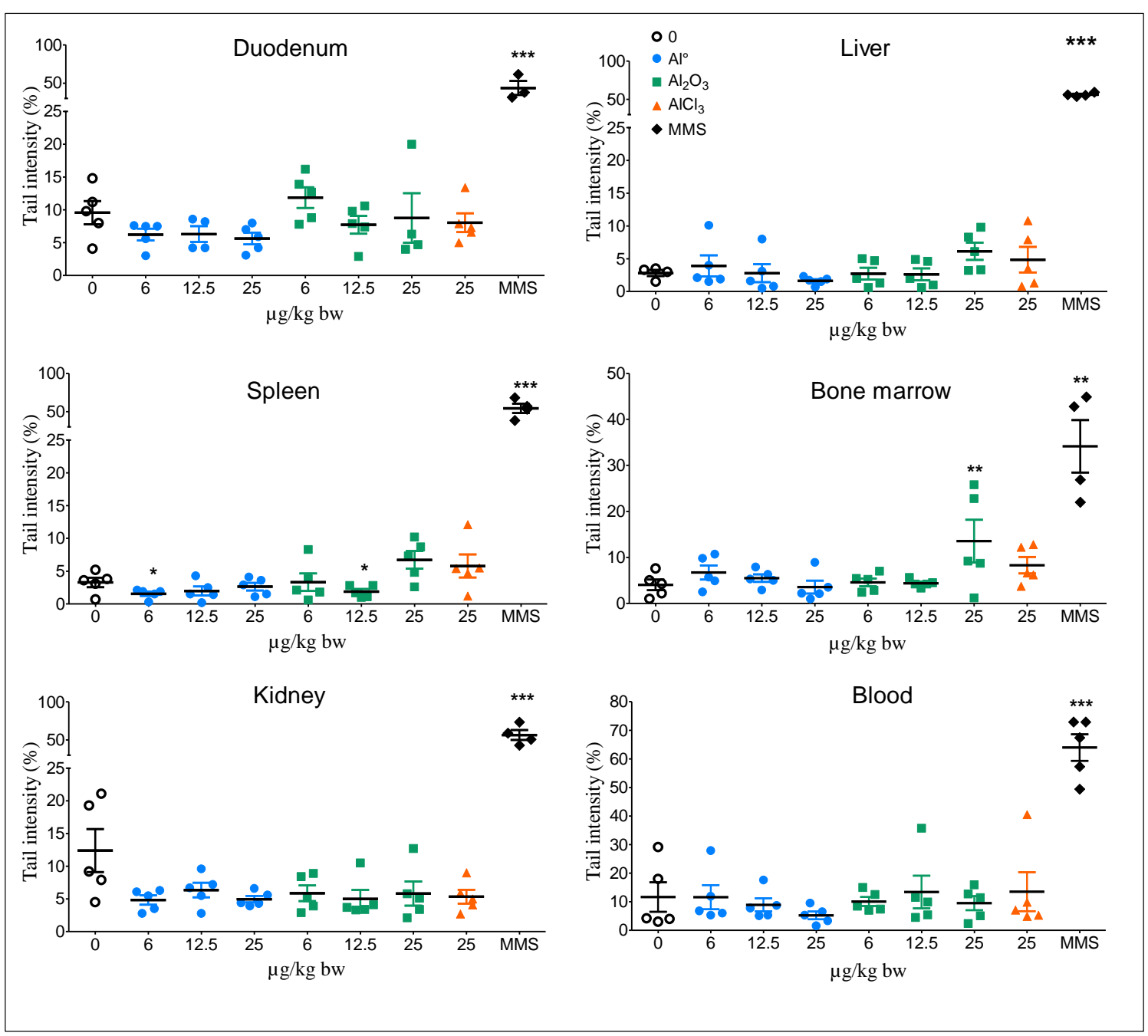

Figure 1. DNA damage in organs/tissues of rats orally exposed to $\mathrm{Al}^{0} \mathrm{NMs}, \mathrm{Al}_{2} \mathrm{O}_{3} \mathrm{NMs}$ or $\mathrm{AlCl}_{3}$. A group treated with the vehicle (0, negative control) and a group treated with a genotoxic agent (MMS, positive control) were included. Significant from control at ${ }^{* *} p<0.01, * * * p<0.001$.

$\mathrm{AlCl}_{3}$ did not induce increases in the DNA tail intensity irrespective of the organ or tissue investigated compared to the vehicle control group.

The data for oxidative DNA damage using the modified Fpg comet assay are shown in Figure 2. No increase in tail intensity was observed in any organ or tissue from rats treated with $\mathrm{Al}^{0}$ and $\mathrm{Al}_{2} \mathrm{O}_{3}$ NMs. However, a significant decrease in tail intensity was detected in the duodenums of rats treated with $\mathrm{Al}^{0} \mathrm{NMs}$ for the three doses. An increase in oxidative lesions, although not statistically significant, was observed in the blood of rats treated with $\mathrm{AlCl}_{3}$ at $25 \mathrm{mg} / \mathrm{kg}$ bw.

The positive control MMS induced a significant increase in tail intensity for all organs with and without Fpg $\left({ }^{* * *} p<0.001\right)$.

With the exception of the positive control MMS, the number of hedgehogs was generally low for all treated groups and tissues in the modified Fpg comet assay except for kidney and spleen (Supplementary Tables S2 and S3). 


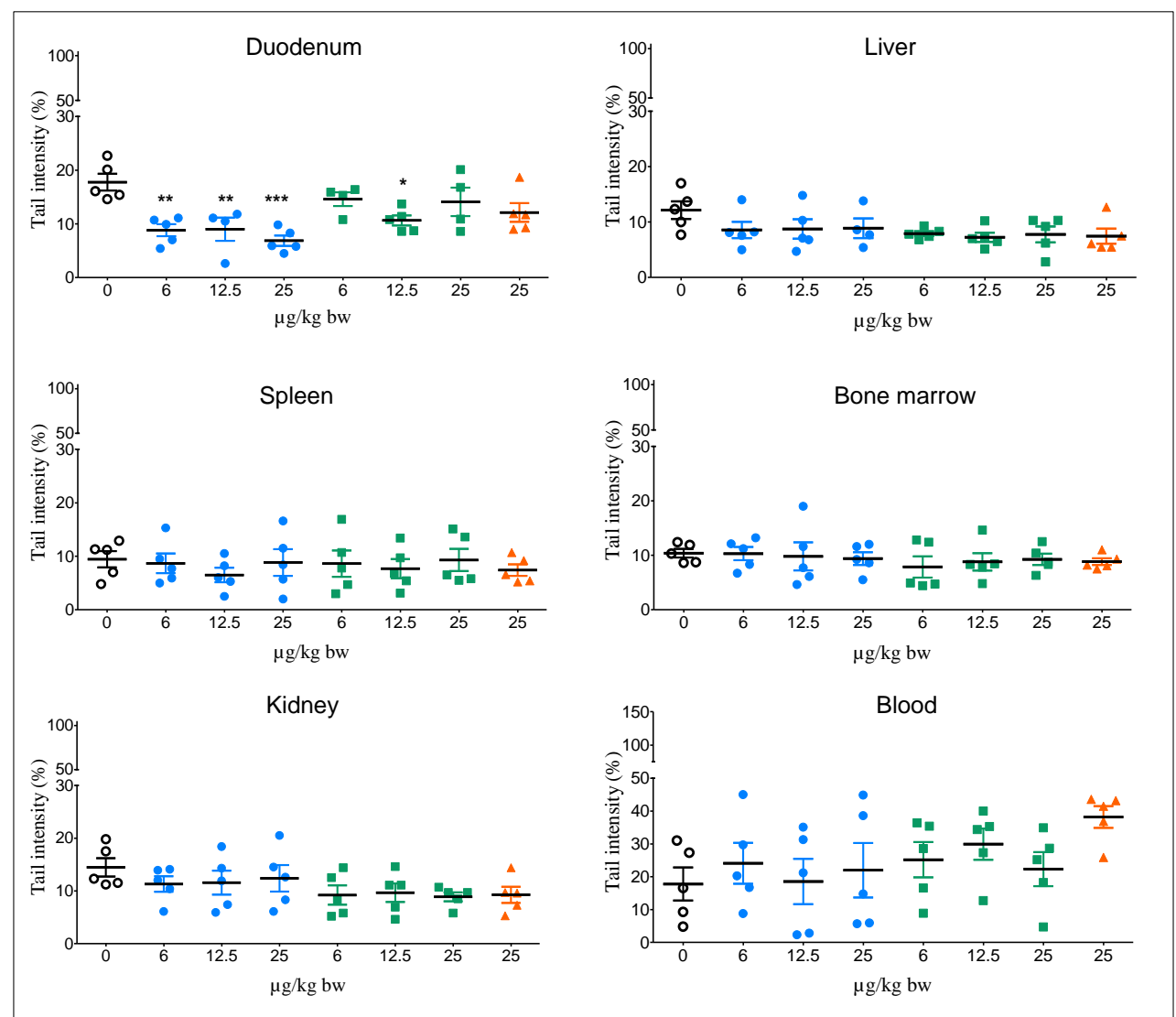

Figure 2. Oxidative DNA damage in different organs/tissues of rats orally exposed to $\mathrm{Al}^{0} \mathrm{NMs}_{2} \mathrm{Al}_{2} \mathrm{O}_{3}$ $\mathrm{NMs}$ or $\mathrm{AlCl}_{3}$. A group treated with the vehicle (0, negative control) was included. Significant from control at ${ }^{*} p<0.05,{ }^{* *} p<0.01,{ }^{* * *} p<0.001$.

\subsection{Bone Marrow Micronucleus Assay (BMMN)}

The results of the BMMN test conducted after oral exposure to $\mathrm{Al}^{0} \mathrm{NMs}$ and $\mathrm{Al}_{2} \mathrm{O}_{3} \mathrm{NMs}$ at $6,12.5$ or $25 \mathrm{mg} / \mathrm{kg}$ bw, and to $\mathrm{AlCl}_{3}$ at $25 \mathrm{mg} / \mathrm{kg}$ bw, are presented in Table 2.

Table 2. Genotoxicity of $\mathrm{Al}^{0} \mathrm{NMs}, \mathrm{Al}_{2} \mathrm{O}_{3} \mathrm{NMs}$ and $\mathrm{AlCl}_{3}$ in rats treated orally detected by the micronucleus assay in bone marrow.

\begin{tabular}{cccc}
\hline & Genotoxicity & Myelotoxicity \\
\hline & & Micronucleated PCE/2 & 000 PCE \\
& Doses $(\mathrm{mg} / \mathrm{kg} \mathrm{bw} /$ day $)$ & Mean \pm SD & \%CEs \\
\hline Control & & $1.3 \pm 0.91$ & Mean \pm SD \\
\hline & $\mathbf{6}$ & $2.0 \pm 2.0$ & $72.5 \pm 26$ \\
\hline $\mathbf{A l}^{\mathbf{0}}$ & $\mathbf{1 2 . 5}$ & $1.5 \pm 0.8$ & $66.3 \pm 13$ \\
& $\mathbf{2 5}$ & $2.1 \pm 1.0$ & $71.5 \pm 8$ \\
& $\mathbf{6}$ & $1.1 \pm 0.7$ & $74.7 \pm 16$ \\
$\mathbf{A l}_{\mathbf{2}} \mathbf{O}_{\mathbf{3}}$ & $\mathbf{1 2 . 5}$ & $1.6 \pm 1.3$ & $68.4 \pm 18$ \\
& $\mathbf{2 5}$ & $0.9 \pm 0.8$ & $65.8 \pm 17$ \\
$\mathbf{A l C l}_{\mathbf{3}}$ & $\mathbf{2 5}$ & $1.5 \pm 0.7$ & $56.7 \pm 17$ \\
\hline $\mathbf{M M S}$ & $\mathbf{1 0 0} \mathbf{1 0 0 , 8 0}$ & $16.7 \pm 3.7 *$ & $65.9 \pm 19$ \\
\hline
\end{tabular}

NCE: normochromatic erythrocytes; PCEs: polychromatic erythrocytes; results correspond to mean $\pm S D, n=5$; ${ }^{*} p<0.001$ with the Pearson X2 with Yate's correction. 
The two Al-NMs did not induce any significant changes in the percentage of MN-PCEs compared to the control group. No significant myelotoxicity was found with either Al-NMs or $\mathrm{AlCl}_{3}$.

The positive control group treated with MMS demonstrated a significant increase in MN-PCEs and a decrease of the percentage of PCEs.

\subsection{Micronucleus Assay in Colon}

The micronucleus assay in colon (Figure 3) showed that the two $\mathrm{Al}-\mathrm{NMs}$ and $\mathrm{AlCl}_{3}$ did not induce any significant increase in micronucleated cells compared to control rats. Similarly, no increase in mitosis and apoptosis was detected with the three Al forms. With the positive control MMS, only a significant increase in the level of apoptotic figures was detected.
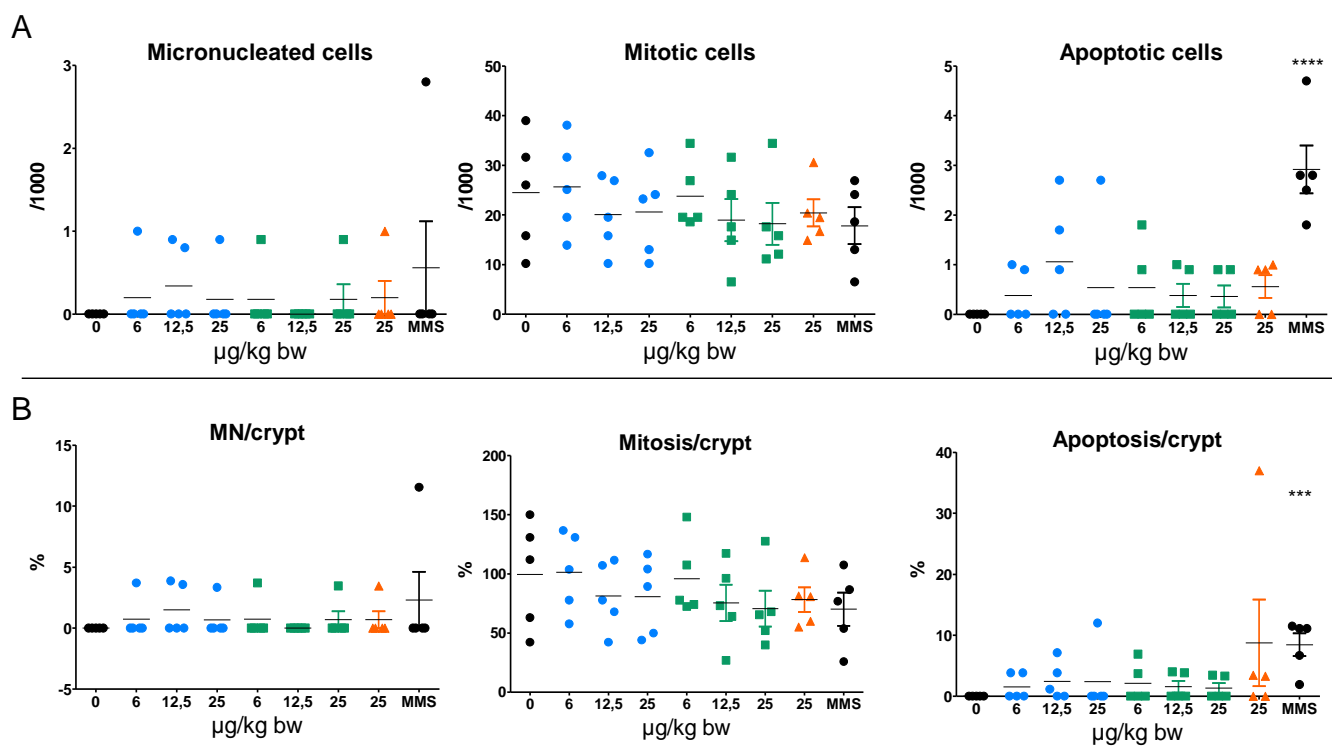

C

D

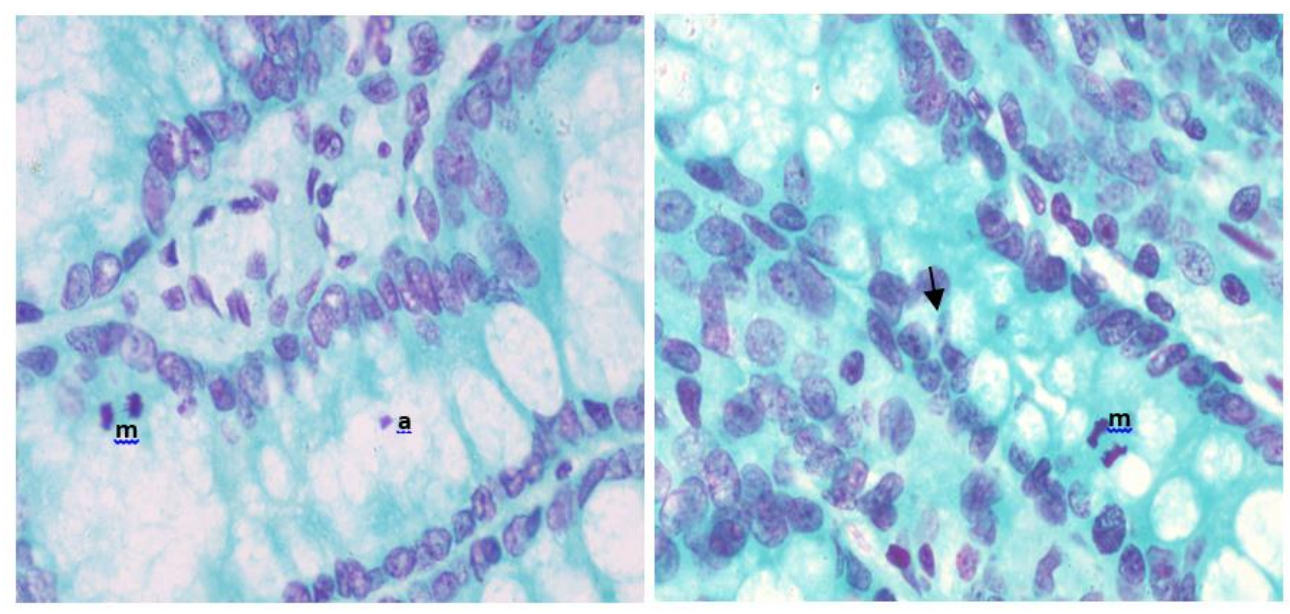

Figure 3. (A) MN, mitotic and apoptotic frequencies per 1000 cells in the colon of rats orally exposed to $\mathrm{Al} \mathrm{NMs}$ and $\mathrm{AlCl}_{3}$ or to the solvent control (0). (B) $\mathrm{MN}$, mitosis and apoptosis percentages per crypt. Results correspond to individual values with mean \pm SD $(n=5)$. Significant from control at ${ }^{* * *} p<0.001,{ }^{* * * *} p<0.0001$ compared to the vehicle control. (C,D) Schiff's reagent and fast green counterstained colon sections of rats treated with MMS (C) and $\mathrm{Al}^{0} \mathrm{NMs}$ at $12.5 \mathrm{mg} / \mathrm{kg}$ bw (D). Black arrow indicates micronuclei in cells. a: apoptosis, m: mitosis. 


\section{Discussion}

To date, published data on the oral genotoxicity of Al-containing NMs are scarce. In this study, we investigated the genotoxic potentials of two nanoforms $\left(\mathrm{Al}^{0}\right.$ and $\left.\mathrm{Al}_{2} \mathrm{O}_{3}\right)$ by applying the in vivo OECD guidelines for the comet assay in several key tissues/organs [27], and the micronucleus assay on bone marrow [32] and on colons. In addition, we have compared the responses with the ionic form $\mathrm{AlCl}_{3}$.

The micronucleus assay both on $\mathrm{BM}$ and on colon was negative with $\mathrm{Al}^{0}$ and $\mathrm{Al}_{2} \mathrm{O}_{3} \mathrm{NMs} \mathrm{up}$ to $25 \mathrm{mg} / \mathrm{kg}$ bw indicating that no chromosome or genome mutations were induced in these two organs. Similarly, a negative response was observed in the blood of rats exposed orally to $\mathrm{Al}_{2} \mathrm{O}_{3} \mathrm{NMs}$ (30 nm and $40 \mathrm{~nm}$ ) at a unique dose of $500 \mathrm{mg} / \mathrm{kg}$ bw. However, doses above $1000 \mathrm{mg} / \mathrm{kg}$ bw induced the formation of $\mathrm{MN}$, concomitantly to high levels of Al content in several organs, including blood, liver, spleen and kidney [11]. Nevertheless, such doses are very high and far from human exposure. Intraperitoneal injection of nano- and bulk-Al from 300 to $1200 \mu \mathrm{g} / \mathrm{kg}$ bw in male and female mice did not provoke any increase of $\mathrm{MN}$ in $\mathrm{BM}$ [33]. In vitro, $\mathrm{Al}_{2} \mathrm{O}_{3} \mathrm{NMs}$ were found to induce $\mathrm{MN}$ in a concentration dependent manner after $24 \mathrm{~h}$ exposure from $0.5 \mu \mathrm{g} / \mathrm{mL}$ in Chinese hamster cells CHOK1 [19] and in human fibroblasts at 13.3 and $26.6 \mu \mathrm{g} / \mathrm{cm}^{2}$ (50 and $\left.100 \mu \mathrm{g} / \mathrm{mL}\right)$ [16]. In contrast, no MN increase was found in human blood lymphocytes [34] or RAW 264 macrophages exposed for $72 \mathrm{~h}$ to $\mathrm{Al}_{2} \mathrm{O}_{3} \mathrm{NMs}$ [35]. A negative response was also observed with the chromosome aberrations assay in human lymphocytes with $\mathrm{Al}_{2} \mathrm{O}_{3} \mathrm{NMs}$ [18]. Similarly, with the same NMs and dispersion protocol used in our study, we did not detect any increase of $\mathrm{MN}$ in human intestinal Caco-2 cells and hepatic HepaRG cells for $\mathrm{Al}^{0}$ and $\mathrm{Al}_{2} \mathrm{O}_{3} \mathrm{NMs}$ up to $80 \mu \mathrm{g} / \mathrm{cm}^{2}$ and for $\mathrm{AlCl}_{3}$ following $24 \mathrm{~h}$ exposure [36].

No DNA damage was observed in the alkaline comet assay in any of the six organs/tissues investigated from rats orally-exposed to $\mathrm{Al}^{0} \mathrm{NMs}$ up to $25 \mathrm{mg} / \mathrm{kg}$ bw. Nevertheless, a decrease of the tail intensity was observed in duodenum that may be a result of cross-links induced by NMs, preventing the DNA migration, as described in the literature [37]. In fact, such a cross-linking effect has been recently described in plants treated with $\mathrm{AlCl}_{3}$, and it was suggested that $\mathrm{Al}$ may interact with DNA in an electrostatic manner [38]. Further data are necessary to confirm this hypothesis. Due to interference of $\mathrm{Al}^{0} \mathrm{NMs}$ with the assay in vitro, the genotoxic potential of these NMs on hepatic and intestinal cell lines is unclear [36].

In this study we have shown induced DNA damage in $\mathrm{BM}$ of rats exposed to $25 \mathrm{mg} / \mathrm{kg} \mathrm{bw} \mathrm{Al}_{2} \mathrm{O}_{3}$ NMs but not in the other organs or tissues investigated. Balasubramanyam et al. (2009) observed an increase of DNA damage in blood of rats up to $48 \mathrm{~h}$ after a single treatment with 30 and $40 \mathrm{~nm}^{\mathrm{Al}_{2} \mathrm{O}_{3}}$ NMs by gavage; however, this was observed at very high doses (above $1000 \mathrm{mg} / \mathrm{kg}$ ) [11]. Recently, DNA fragmentation due to cell death (both necrosis and apoptosis) was reported in liver and kidney of rats treated orally for 75 days with $70 \mathrm{mg} / \mathrm{kg}$ bw $\mathrm{Al}_{2} \mathrm{O}_{3} \mathrm{NMs}$ [39]. Two other studies have investigated the genotoxic potential of $\mathrm{Al}_{2} \mathrm{O}_{3} \mathrm{NMs}$ after intraperitoneal administration. These have demonstrated DNA damage in blood after 6 weeks of repeated exposure at $1.25 \mathrm{mg} / \mathrm{kg}$ bw [40] and in the brains of rats $48 \mathrm{~h}$ after a single intraperitoneal administration of $\mathrm{Al}_{2} \mathrm{O}_{3} \mathrm{NMs}$, although at very high doses (from 4 to $8.5 \mathrm{~g} / \mathrm{kg} \mathrm{bw}$ ) which were evaluated as lethal (from 30 to $65 \%$ of the LD50) in the same study [41]. In this study, the DNA damage was correlated with Al accumulation in several organs, including the brain.

In vitro, time- and concentration-dependent DNA damage was found in Chinese hamster lung fibroblasts [33] and in liver HepG2 cells [17] exposed to $\mathrm{Al}_{2} \mathrm{O}_{3} \mathrm{NMs}$ from $30 \mu \mathrm{g} / \mathrm{mL}$. However, other studies have reported negative responses in human peripheral blood cells and human embryonic kidney cells up to $100 \mu \mathrm{g} / \mathrm{mL}$ following a $3 \mathrm{~h}$ treatment [42], and in human lymphocytes at $100 \mu \mathrm{g} / \mathrm{mL}$ after a $24 \mathrm{~h}$ exposure [18]. Recently, it was shown that $\mathrm{Al}_{2} \mathrm{O}_{3}$ NMs can inhibit DNA polymerase replication but without affecting mutation rate compared to controls [43].

To investigate if oxidative DNA damage can be increased with Al NMs, we performed the Fpg-modified comet assay. Neither $\mathrm{Al}^{0}$ nor $\mathrm{Al}_{2} \mathrm{O}_{3} \mathrm{NMs}$ induced oxidative DNA damage in six different organs of rats exposed to $6-25 \mathrm{mg} / \mathrm{kg}$ bw. Although in this study we did not observe an increase in 
oxidative DNA damage with $\mathrm{Al}_{2} \mathrm{O}_{3} \mathrm{NMs}$, Shah et al. (2015) reported an increase in 8-oxo guanine, an oxidized DNA base, in vivo in the brain of mice treated intraperitoneally with $50 \mathrm{mg} / \mathrm{kg} \mathrm{Al}{ }_{2} \mathrm{O}_{3}$ $\mathrm{NMs}$ [44]. Similar results were observed in vitro in mouse neuronal cells treated with $\mathrm{Al}_{2} \mathrm{O}_{3} \mathrm{NMs}$ from 100 to $150 \mu \mathrm{g} / \mathrm{mL}$ [44].

Several metal oxide NMs have been shown to induce oxidative stress $[13,14,18,33,45,46]$ which in some cases was correlated with DNA damage [47]. Several in vivo studies with Al NMs have described a concentration-dependent increase in oxidative stress with $\mathrm{Al}_{2} \mathrm{O}_{3} \mathrm{NMs}$ in several tissues including liver and kidney induced after acute (3 days) and chronic (up to 21 days) oral exposures to rats at doses ranging from 500 to $2000 \mathrm{mg} / \mathrm{kg}$ bw $[13,14]$. Moreover, oxidative stress was observed in several organs of rodents following acute and repeated intraperitoneal exposure [44,48]. Using doses of $\mathrm{Al}_{2} \mathrm{O}_{3} \mathrm{NMs}$ more consistent with daily human exposure ( 0.5 to $70 \mathrm{mg} / \mathrm{kg} \mathrm{bw}$ ), oxidative stress was detected in rat liver, kidney and erythrocytes after repeated daily oral exposure [39,45,49]. In vitro, some evidence that exposure to $\mathrm{Al}_{2} \mathrm{O}_{3} \mathrm{NMs}$ can induce oxidative stress has been also reported in various cell lines following $24 \mathrm{~h}$ exposure $[18,33,44,46,47]$ that can be rapidly repaired depending on the concentration [47]. In contrast, Demir et al. (2015) did not observe any oxidative DNA damage in human peripheral blood cells exposed $3 \mathrm{~h}$ to $\mathrm{Al}_{2} \mathrm{O}_{3} \mathrm{NMs}$ up to $10 \mu \mathrm{g} / \mathrm{mL}$ [50]. It was also shown that impairment of mineral homeostasis linked to oxidative stress could be induced by $\mathrm{Al}_{2} \mathrm{O}_{3} \mathrm{NMs}$ in hippocampi of rats after intravenous injections [51].

In agreement with our results for $\mathrm{Al}^{\mathrm{O}}$ and $\mathrm{Al}_{2} \mathrm{O}_{3} \mathrm{NMs}$, no increase in MN was observed in either in $\mathrm{BM}$ or colons of rats exposed to $25 \mathrm{mg} / \mathrm{kg} \mathrm{bw} \mathrm{AlCl}_{3}$. In other studies, however, $\mathrm{AlCl}_{3}$ was found to increase the number of $\mathrm{MN}$ in BM after a unique oral exposure to mice at $50 \mathrm{mg} / \mathrm{kg}$ bw [22]. Likewise, increases in $\mathrm{MN}$ frequency were observed in rat liver after a 30 day oral exposure [52] or with a $5 \mathrm{mg} / \mathrm{kg}$ bw daily intra-peritoneal exposure for 10 weeks [53]. Interestingly, the induction of $\mathrm{MN}$ formation following oral exposure could be decreased with an antioxidant treatment (propolis or borax) [52,54] suggesting that the effects of $\mathrm{AlCl}_{3}$ where linked to oxidative stress as described elsewhere [55-57]. Nevertheless, apoptosis has been described as a cause of DNA fragmentation in the liver of mice following acute exposures to $\mathrm{AlCl}_{3}(25 \mathrm{mg} / \mathrm{kg}$ by ip) [58]. Aluminum acetate $(50 \mathrm{mg} / \mathrm{kg})$ was also found to induce chromosome aberrations in BM of mice after both single and seven consecutive day intraperitoneal administration while the $\mathrm{MN}$ response was only positive after repeated exposure [59]. In vitro, $\mathrm{AlCl}_{3}$ was reported to increase the number of $\mathrm{MN}$ and chromosomal aberrations in peripheral blood lymphocytes after $24 \mathrm{~h}$ exposure between 1 and $10 \mu \mathrm{g} / \mathrm{mL}$ [60].

We did not observe any increase in DNA damage with the comet assay in duodenum and liver, in agreement with our in vitro results on liver and intestinal human cells [36]. No DNA damage, with or without Fpg, was detected in the other organs and tissues investigated, with the exception of blood where a slight increase of oxidative DNA damage was observed. Indeed, DNA damage in response to $\mathrm{AlCl}_{3}$ exposure was reported in vitro in human peripheral blood cells [20,21]. Oxidative stress in response to $\mathrm{AlCl}_{3}$ treatment was demonstrated to correlate with oxidative DNA damage induced in human peripheral blood cells [21] and the increase of GSH/GSSG ratio and Hsp70 mRNA levels in human neuroblastoma cells [61].

While a negative response in the $\mathrm{MN}$ assay was observed with the three forms of $\mathrm{Al}$ both in vitro and in vivo, the comet assay indicated effects of $\mathrm{Al}_{2} \mathrm{O}_{3} \mathrm{NMs}$ on $\mathrm{BM}$ and with $\mathrm{AlCl}_{3}$ on blood. No correlation between the in vivo genotoxicity of $\mathrm{Al} \mathrm{NMs}$ and the ionic salt $\mathrm{AlCl}_{3}$ was observed in our study, and we therefore cannot conclusively determine the potential effect of aluminum ions released from the Al NMs. Although we have previously reported a low solubility of these Al-containing NMs in an in vitro digestion system [25], estimating the solubility of NMs in the intestinal fluid in vivo remains challenging. Therefore, no clear conclusion can be drawn on the role, if any, of metallic ions in the genotoxic effects observed. The differences due to the route of exposure, the Al form tested, the organs studied and the dose of exposure can explain the discrepancies of the responses in the different publications. 


\section{Conclusions}

Our results indicate that $\mathrm{Al}^{0}$ and $\mathrm{Al}_{2} \mathrm{O}_{3} \mathrm{NMs}$ do not induce chromosomal mutations detected by the micronucleus assay in BM or the colons of rats exposed orally to Al-containing NMs at doses from 6 to $25 \mathrm{mg} / \mathrm{kg}$ bw. However, the comet assay showed some increase of DNA damage only in BM with $\mathrm{Al}_{2} \mathrm{O}_{3} \mathrm{NMs}$, while $\mathrm{AlCl}_{3}$ induced slight oxidative DNA damage in blood. No clear relationship between genotoxic effects and ion release could be determined. Challenges remain in the evaluation of the genotoxicity of Al-containing NMs, and further work is necessary in order to correlate these data with the measurement and characterization of Al NMs in the different organs and body fluids, including data on solubility in vivo.

Supplementary Materials: The following are available online at http://www.mdpi.com/2079-4991/10/2/305/s1. Figure S1: Equivalence between the doses administrated between mass and Al content., Table S1: Percentage of hedgehogs scored on the comet slides without Fpg. Mean \pm SD $(n=5$ animals per condition except for control duodenum $n=4)$., Table S2: Percentage of hedgehogs scored on the comet slides with Fpg. Mean \pm SD $(n=5$ animals per condition).

Author Contributions: Conceptualization, V.F.; formal analysis, P.J., L.L.H., F.N., K.H. and V.F.; funding acquisition, V.F.; investigation, P.J., S.H., R.L. and G.J.; methodology, P.J., S.H., R.L., G.J. and L.L.H.; project administration, P.J. and V.F.; resources, P.J., S.H., R.L., G.J. and L.L.H.; supervision, F.N., K.H. and V.F.; visualization, P.J.; writing-original draft, P.J.; writing-review and editing, K.H. and V.F. All authors have read and agree to the published version of the manuscript.

Funding: This publication arises from the French-German bilateral project SolNanoTOX funded by the French National Research Agency (ANR, Project ID: ANR-13-IS10-0005) and the German Research Foundation (DFG, Project ID: DFG (FKZ LA 3411/1-1 respectively LA 1177/9-1).

Acknowledgments: The authors would like to thank Jean-Guy Rolland, Gonzague Dourdin and Eulalie Gateau for their technical support.

Conflicts of Interest: The authors declare that there are no conflicts of interest.

\section{References}

1. European Food Safety Authority. Safety of aluminium from dietary intake-Scientific Opinion of the Panel on Food Additives, Flavourings, Processing Aids and Food Contact Materials (AFC). EFSA J. 2008, 6, 754.

2. Willhite, C.C.; Karyakina, N.A.; Yokel, R.A.; Yenugadhati, N.; Wisniewski, T.M.; Arnold, I.M.; Momoli, F.; Krewski, D. Systematic review of potential health risks posed by pharmaceutical, occupational and consumer exposures to metallic and nanoscale aluminum, aluminum oxides, aluminum hydroxide and its soluble salts. Crit. Rev. Toxicol. 2014, 44,1-80. [CrossRef] [PubMed]

3. Vignal, C.; Desreumaux, P.; Body-Malapel, M. Gut: An underestimated target organ for Aluminum. Morphologie 2016, 100, 75-84. [CrossRef] [PubMed]

4. Saiyed, S.M.; Yokel, R.A. Aluminium content of some foods and food products in the USA, with aluminium food additives. Food Addit. Contam. 2005, 22, 234-244. [CrossRef] [PubMed]

5. Krewski, D.; Yokel, R.A.; Nieboer, E.; Borchelt, D.; Cohen, J.; Harry, J.; Kacew, S.; Lindsay, J.; Mahfouz, A.M.; Rondeau, V. Human health risk assessment for aluminium, aluminium oxide, and aluminium hydroxide. J. Toxicol. Environ. Health. B Crit. Rev. 2007, 10,1-269. [CrossRef] [PubMed]

6. Gehrke, I.; Geiser, A.; Somborn-Schulz, A. Innovations in nanotechnology for water treatment. Nanotechnol. Sci. Appl. 2015, 8, 1-17. [CrossRef] [PubMed]

7. Zhao, J.; Castranova, V. Toxicology of nanomaterials used in nanomedicine. J. Toxicol. Environ. Health B Crit. Rev. 2011, 14, 593-632. [CrossRef]

8. Frey, A.; Neutra, M.R.; Robey, F.A. Peptomer aluminum oxide nanoparticle conjugates as systemic and mucosal vaccine candidates: Synthesis and characterization of a conjugate derived from the C4 domain of HIV-1MN gp120. Bioconjug. Chem. 1997, 8, 424-433. [CrossRef]

9. Narayan, R.J.; Adiga, S.P.; Pellin, M.J.; Curtiss, L.A.; Hryn, A.J.; Stafslien, S.; Chisholm, B.; Shih, C.-C.; Shih, C.-M.; Lin, S.-J.; et al. Atomic layer deposition-based functionalization of materials for medical and environmental health applications. Philos. Trans. R. Soc. A Math. Phys. Eng. Sci. 2010, 368, 2033-2064. [CrossRef] 
10. JECFA Summary and Conclusions of the Sixty-Seventh Meeting of the Joint FAO/WHO Expert Committee on Food Additives (JECFA). Available online: http://www.fao.org/3/a-at874e.pdf (accessed on 1 February 2020).

11. Balasubramanyam, A.; Sailaja, N.; Mahboob, M.; Rahman, M.F.; Misra, S.; Hussain, S.M.; Grover, P. Evaluation of genotoxic effects of oral exposure to aluminum oxide nanomaterials in rat bone marrow. Mutat. Res. 2009, 676, 41-47. [CrossRef]

12. Park, E.J.; Sim, J.; Kim, Y.; Han, B.S.; Yoon, C.; Lee, S.; Cho, M.H.; Lee, B.S.; Kim, J.H. A 13-week repeated-dose oral toxicity and bioaccumulation of aluminum oxide nanoparticles in mice. Arch. Toxicol. 2015, 89, 371-379. [CrossRef] [PubMed]

13. Shrivastava, R.; Raza, S.; Yadav, A.; Kushwaha, P.; Flora, S.J. Effects of sub-acute exposure to TiO2, ZnO and $\mathrm{Al} 2 \mathrm{O} 3$ nanoparticles on oxidative stress and histological changes in mouse liver and brain. Drug Chem. Toxicol. 2014, 37, 336-347. [CrossRef] [PubMed]

14. Prabhakar, P.V.; Reddy, U.A.; Singh, S.P.; Balasubramanyam, A.; Rahman, M.F.; Indu Kumari, S.; Agawane, S.B.; Murty, U.S.; Grover, P.; Mahboob, M. Oxidative stress induced by aluminum oxide nanomaterials after acute oral treatment in Wistar rats. J. Appl. Toxicol. 2012, 32, 436-445. [CrossRef] [PubMed]

15. ECHA. Registration dossier Aluminum oxide. Available online: https://echa.europa.eu/fr/registrationdossier/-/registered-dossier/16039/7/7/1 (accessed on 5 January 2020).

16. Tsaousi, A.; Jones, E.; Case, C.P. The in vitro genotoxicity of orthopaedic ceramic (Al2O3) and metal (CoCr alloy) particles. Mutat. Res. 2010, 697, 1-9. [CrossRef] [PubMed]

17. Alarifi, S.; Ali, D.; Alkahtani, S. Nanoalumina induces apoptosis by impairing antioxidant enzyme systems in human hepatocarcinoma cells. Int. J. Nanomed. 2015, 10, 3751-3760.

18. Rajiv, S.; Jerobin, J.; Saranya, V.; Nainawat, M.; Sharma, A.; Makwana, P.; Gayathri, C.; Bharath, L.; Singh, M.; Kumar, M.; et al. Comparative cytotoxicity and genotoxicity of cobalt (II, III) oxide, iron (III) oxide, silicon dioxide, and aluminum oxide nanoparticles on human lymphocytes in vitro. Hum. Exp. Toxicol. 2016, 35, 170-183. [CrossRef]

19. Di Virgilio, A.L.; Reigosa, M.; Arnal, P.M.; Fernandez Lorenzo de Mele, M. Comparative study of the cytotoxic and genotoxic effects of titanium oxide and aluminium oxide nanoparticles in Chinese hamster ovary (CHO-K1) cells. J. Hazard. Mater. 2010, 177, 711-718. [CrossRef]

20. Lima, P.D.; Leite, D.S.; Vasconcellos, M.C.; Cavalcanti, B.C.; Santos, R.A.; Costa-Lotufo, L.V.; Pessoa, C.; Moraes, M.O.; Burbano, R.R. Genotoxic effects of aluminum chloride in cultured human lymphocytes treated in different phases of cell cycle. Food Chem. Toxicol. 2007, 45, 1154-1159. [CrossRef]

21. Lankoff, A.; Banasik, A.; Duma, A.; Ochniak, E.; Lisowska, H.; Kuszewski, T.; Gozdz, S.; Wojcik, A. A comet assay study reveals that aluminium induces DNA damage and inhibits the repair of radiation-induced lesions in human peripheral blood lymphocytes. Toxicol. Lett. 2006, 161, 27-36. [CrossRef]

22. Paz, L.N.; Moura, L.M.; Feio, D.C.; Cardoso, M.S.; Ximenes, W.L.; Montenegro, R.C.; Alves, A.P.; Burbano, R.R.; Lima, P.D. Evaluation of in vivo and in vitro toxicological and genotoxic potential of aluminum chloride. Chemosphere 2017, 175, 130-137. [CrossRef]

23. Hartmann, N.B.; Jensen, K.A.; Baun, A.; Rasmussen, K.; Rauscher, H.; Tantra, R.; Cupi, D.; Gilliland, D.; Pianella, F.; Riego Sintes, J.M. Techniques and Protocols for Dispersing Nanoparticle Powders in Aqueous Media-Is there a Rationale for Harmonization? J. Toxicol. Environ. Health B Crit. Rev. 2015, 18, $299-326$. [CrossRef] [PubMed]

24. Jensen, K.A.; Kembouche, Y.; Christiansen, E.; Jacobsen, N.R.; Wallin, H.; Guiot, C.; Spalla, O.; Witschger, O. Final Protocol for Producing Suitable Manufactured Nanomaterial Exposure Media. Web-Report. The Generic NANOGENOTOX Dispersion Protocol—Standard Operation Procedure (SOP). Available online: https://www.anses.fr/en/system/files/nanogenotox_deliverable_5.pdf (accessed on 1 February 2020).

25. Sieg, H.; Kastner, C.; Krause, B.; Meyer, T.; Burel, A.; Bohmert, L.; Lichtenstein, D.; Jungnickel, H.; Tentschert, J.; Laux, P.; et al. Impact of an Artificial Digestion Procedure on Aluminum-Containing Nanomaterials. Langmuir 2017, 33, 10726-10735. [CrossRef] [PubMed]

26. Krause, B.; Meyer, T.; Sieg, H.; Kästner, C.; Reichardt, P.; Tentschert, J.; Jungnickel, H.; Estrela-Lopis, I.; Burel, A.; Chevance, S.; et al. Characterization of aluminum, aluminum oxide and titanium dioxide nanomaterials using a combination of methods for particle surface and size analysis. RSC Adv. 2018, 8, 14377-14388. [CrossRef]

27. OCDE. Test No. 489: In Vivo Mammalian Alkaline Comet Assay; OECD Publishing: Paris, France, 2016. 
28. Tarantini, A.; Huet, S.; Jarry, G.; Lanceleur, R.; Poul, M.; Tavares, A.; Vital, N.; Louro, H.; Joao Silva, M.; Fessard, V. Genotoxicity of synthetic amorphous silica nanoparticles in rats following short-term exposure. Part 1: Oral route. Environ. Mol. Mutagen. 2015, 56, 218-227. [CrossRef]

29. McKelvey-Martin, V.J.; Green, M.H.; Schmezer, P.; Pool-Zobel, B.L.; De Meo, M.P.; Collins, A. The single cell gel electrophoresis assay (comet assay): A European review. Mutat. Res. 1993, 288, 47-63. [CrossRef]

30. Zeller, A.; Duran-Pacheco, G.; Guerard, M. An appraisal of critical effect sizes for the benchmark dose approach to assess dose-response relationships in genetic toxicology. Arch. Toxicol. 2017, 91, 3799-3807. [CrossRef]

31. Tice, R.R.; Agurell, E.; Anderson, D.; Burlinson, B.; Hartmann, A.; Kobayashi, H.; Miyamae, Y.; Rojas, E.; Ryu, J.C.; Sasaki, Y.F. Single cell gel/comet assay: Guidelines for in vitro and in vivo genetic toxicology testing. Environ. Mol. Mutagen. 2000, 35, 206-221. [CrossRef]

32. OCDE. Test No. 474: Mammalian Erythrocyte Micronucleus Test; OECD Publishing: Paris, France, 2016.

33. Zhang, Q.; Wang, H.; Ge, C.; Duncan, J.; He, K.; Adeosun, S.O.; Xi, H.; Peng, H.; Niu, Q. Alumina at 50 and $13 \mathrm{~nm}$ nanoparticle sizes have potential genotoxicity. J. Appl. Toxicol. 2017, 37, 1053-1064. [CrossRef]

34. Akbaba, G.B.; Turkez, H. Investigation of the Genotoxicity of Aluminum Oxide, beta-Tricalcium Phosphate, and Zinc Oxide Nanoparticles In Vitro. Int. J. Toxicol. 2018, 37, 216-222. [CrossRef]

35. Hashimoto, M.; Imazato, S. Cytotoxic and genotoxic characterization of aluminum and silicon oxide nanoparticles in macrophages. Dent. Mater. 2015, 31, 556-564. [CrossRef]

36. Jalili, P.; Huet, S.; Burel, A.; Krause, B.-C.; Fontana, C.; Gauffre, F.; Guichard, Y.; Laux, P.; Luch, A.; Hogeveen, K.; et al. Genotoxic impact of aluminum-containing nanomaterials in human intestinal and hepatic cells. Manuscript in preparation.

37. McKenna, D.J.; Gallus, M.; McKeown, S.R.; Downes, C.S.; McKelvey-Martin, V.J. Modification of the alkaline Comet assay to allow simultaneous evaluation of mitomycin C-induced DNA cross-link damage and repair of specific DNA sequences in RT4 cells. DNA Repair 2003, 2, 879-890. [CrossRef]

38. Chen, P.; Sjogren, C.A.; Larsen, P.B.; Schnittger, A. A multi-level response to DNA damage induced by aluminium. Plant J. 2019, 98, 479-491. [CrossRef] [PubMed]

39. Yousef, M.I.; Mutar, T.F.; Kamel, M.A.E. Hepato-renal toxicity of oral sub-chronic exposure to aluminum oxide and/or zinc oxide nanoparticles in rats. Toxicol. Rep. 2019, 6, 336-346. [CrossRef] [PubMed]

40. Minigalieva, I.A.; Katsnelson, B.A.; Privalova, L.I.; Sutunkova, M.P.; Gurvich, V.B.; Shur, V.Y.; Shishkina, E.V.; Valamina, I.E.; Makeyev, O.H.; Panov, V.G.; et al. Combined Subchronic Toxicity of Aluminum (III), Titanium (IV) and Silicon (IV) Oxide Nanoparticles and Its Alleviation with a Complex of Bioprotectors. Int. J. Mol. Sci. 2018, 19, 837. [CrossRef]

41. Morsy, G.M.; El-Ala, K.S.; Ali, A.A. Studies on fate and toxicity of nanoalumina in male albino rats: Lethality, bioaccumulation and genotoxicity. Toxicol. Ind. Health 2016, 32, 344-359. [CrossRef]

42. Demir, E.; Akca, H.; Turna, F.; Aksakal, S.; Burgucu, D.; Kaya, B.; Tokgun, O.; Vales, G.; Creus, A.; Marcos, R. Genotoxic and cell-transforming effects of titanium dioxide nanoparticles. Environ. Res. 2015, 136, 300-308. [CrossRef]

43. Gao, C.-H.; Mortimer, M.; Zhang, M.; Holden, P.A.; Cai, P.; Wu, S.; Xin, Y.; Wu, Y.; Huang, Q. Impact of metal oxide nanoparticles on in vitro DNA amplification. Peer J. 2019, 7, e7228. [CrossRef]

44. Shah, S.A.; Yoon, G.H.; Ahmad, A.; Ullah, F.; Amin, F.U.; Kim, M.O. Nanoscale-alumina induces oxidative stress and accelerates amyloid beta (A $\beta$ ) production in ICR female mice. Nanoscale 2015, 7, 15225-15237. [CrossRef]

45. Canli, E.G.; Atli, G.; Canli, M. Response of the antioxidant enzymes of the erythrocyte and alterations in the serum biomarkers in rats following oral administration of nanoparticles. Environ. Toxicol. Pharmacol. 2017, 50, 145-150. [CrossRef]

46. Li, X.; Zhang, C.; Zhang, X.; Wang, S.; Meng, Q.; Wu, S.; Yang, H.; Xia, Y.; Chen, R. An acetyl-L-carnitine switch on mitochondrial dysfunction and rescue in the metabolomics study on aluminum oxide nanoparticles. Part Fibre Toxicol. 2016, 13, 4. [CrossRef]

47. Sliwinska, A.; Kwiatkowski, D.; Czarny, P.; Milczarek, J.; Toma, M.; Korycinska, A.; Szemraj, J.; Sliwinski, T. Genotoxicity and cytotoxicity of $\mathrm{ZnO}$ and $\mathrm{Al} 2 \mathrm{O} 3$ nanoparticles. Toxicol. Mech. Methods. 2015, 25, 176-183. [CrossRef] [PubMed] 
48. Morsy, G.M.; El-Ala, K.S.; Ali, A.A. Studies on fate and toxicity of nanoalumina in male albino rats: Some haematological, biochemical and histological aspects. Toxicol. Ind. Health. 2016, 32, 634-655. [CrossRef] [PubMed]

49. Canli, E.G.; Atli, G.; Canli, M. Responses of biomarkers belonging to different metabolic systems of rats following oral administration of aluminium nanoparticle. Environ. Toxicol. Pharm. 2019, 69, 72-79. [CrossRef] [PubMed]

50. Demir, E.; Burgucu, D.; Turna, F.; Aksakal, S.; Kaya, B. Determination of TiO2, ZrO2, and Al2O3 nanoparticles on genotoxic responses in human peripheral blood lymphocytes and cultured embyronic kidney cells. J. Toxicol. Environ. Health A 2013, 76, 990-1002. [CrossRef]

51. M'Rad, I.; Jeljeli, M.; Rihane, N.; Hilber, P.; Sakly, M.; Amara, S. Aluminium oxide nanoparticles compromise spatial learning and memory performance in rats. Excli. J. 2018, 17, 200-210.

52. Turkez, H.; Yousef, M.I.; Geyikoglu, F. Propolis prevents aluminium-induced genetic and hepatic damages in rat liver. Food Chem. Toxicol. 2010, 48, 2741-2746. [CrossRef]

53. Geyikoglu, F.; Turkez, H.; Bakir, T.O.; Cicek, M. The genotoxic, hepatotoxic, nephrotoxic, haematotoxic and histopathological effects in rats after aluminium chronic intoxication. Toxicol. Ind. Health 2013, 29, 780-791. [CrossRef]

54. Turkez, H.; Geyikoglu, F.; Tatar, A. Borax counteracts genotoxicity of aluminum in rat liver. Toxicol. Ind. Health 2013, 29, 775-779. [CrossRef]

55. Cao, Z.; Geng, X.; Jiang, X.; Gao, X.; Liu, K.; Li, Y. Melatonin Attenuates AlCl3-Induced Apoptosis and Osteoblastic Differentiation Suppression by Inhibiting Oxidative Stress in MC3T3-E1 Cells. Biol. Trace Elem. Res. 2019. [CrossRef]

56. Martinez, C.S.; Vera, G.; Ocio, J.A.U.; Pecanha, F.M.; Vassallo, D.V.; Miguel, M.; Wiggers, G.A. Aluminum exposure for 60days at an equivalent human dietary level promotes peripheral dysfunction in rats. J. Inorg. Biochem. 2018, 181, 169-176. [CrossRef]

57. Yang, X.; Yu, K.; Wang, H.; Zhang, H.; Bai, C.; Song, M.; Han, Y.; Shao, B.; Li, Y.; Li, X. Bone impairment caused by $\mathrm{AlCl} 3$ is associated with activation of the JNK apoptotic pathway mediated by oxidative stress. Food Chem. Toxicol. 2018, 116, 307-314. [CrossRef]

58. Cheng, D.; Zhang, X.; Xu, L.; Li, X.; Hou, L.; Wang, C. Protective and prophylactic effects of chlorogenic acid on aluminum-induced acute hepatotoxicity and hematotoxicity in mice. Chem. Interact. 2017, 273, 125-132. [CrossRef] [PubMed]

59. D'Souza, S.P.; Vijayalaxmi, K.K.; Naik, P. Assessment of genotoxicity of aluminium acetate in bone marrow, male germ cells and fetal liver cells of Swiss albino mice. Mutat. Res. Genet. Toxicol. Environ. Mutagen. 2014, 766, 16-22. [CrossRef] [PubMed]

60. Banasik, A.; Lankoff, A.; Piskulak, A.; Adamowska, K.; Lisowska, H.; Wojcik, A. Aluminum-induced micronuclei and apoptosis in human peripheral-blood lymphocytes treated during different phases of the cell cycle. Environ. Toxicol. 2005, 20, 402-406. [CrossRef] [PubMed]

61. Villarini, M.; Gambelunghe, A.; Giustarini, D.; Ambrosini, M.V.; Fatigoni, C.; Rossi, R.; Dominici, L.; Levorato, S.; Muzi, G.; Piobbico, D.; et al. No evidence of DNA damage by co-exposure to extremely low frequency magnetic fields and aluminum on neuroblastoma cell lines. Mutat. Res. 2017, 823, 11-21. [CrossRef]

(C) 2020 by the authors. Licensee MDPI, Basel, Switzerland. This article is an open access article distributed under the terms and conditions of the Creative Commons Attribution (CC BY) license (http://creativecommons.org/licenses/by/4.0/). 